\title{
Urdimento
}

Revista de Estudos em Artes Cênicas

E-ISSN: 2358.6958

\section{Se tudo ficasse quieto conseguiríamos escutar o rio?: uma intervenção urbana sobre memórias da cidade}

\author{
Mariana Zabot Pasqualotto \\ Andréa Vieira Zanella \\ Tânia Galli Fonseca
}

\section{Para citar este artigo:}

PASQUALOTTO, Mariana Zabot; ZANELLA, Andréa Vieira; FONSECA, Tânia Galli. Se tudo ficasse quieto conseguiríamos escutar o rio?: uma intervenção urbana sobre memórias da cidade. Urdimento, Florianópolis, v. 2, n. 38, ago./set. 2020.

DOI: http:/dx.doi.org/10.5965/14145731023820200035

Este artigo passou pelo Plagiarism Detection Software | iThenticate 
Se tudo ficasse quieto conseguiríamos escutar o rio?: Uma intervenção urbana sobre memórias da cidade

\author{
Mariana Zabot Pasqualotto ${ }^{1}$ \\ Andréa Vieira Zanella² \\ Tânia Galli Fonseca
}

\begin{abstract}
Resumo
Este artigo problematiza, a partir de uma intervenção artística realizada no centro de Florianópolis (Santa Catarina/Brasil), algumas tensões entre passado e presente e entre memória e esquecimento constitutivas da cidade. Trata-se da performance Parte da Paisagem, realizada em uma avenida onde antigamente havia um rio. A partir da abertura à produção de uma relação estética com o espaço urbano instigase o olhar ao insignificante, ao esquecido; propõe-se tensionar passado e presente, o aceleramento, o barulho e a parada, a contemplação do silenciado. Instiga-se escutar o que ainda ressoa na cidade das histórias de camadas submersas, proposta que visibiliza a potência deslocadora da arte.
\end{abstract}

Palavras-chave: Memória. Arte. Cidade. Performance. Florianópolis.

If everything went quiet could we hear the river?: An urban intervention about the city's memories

\begin{abstract}
This article problematizes, from an artistic intervention realized in downtown Florianópolis city (Santa Catarina / Brazil), some tensions between past and present and between memory and forgetfulness, all of them constituents of town. The performance discussed in this paper is named Landscape Part, and was presented on a city avenue, where there used to be a river. Providing a breach to an aesthetic relation with urban space instigates the view to what is insignificant and what has been forgotten; proposes to tense the past and the present, the acceleration, the noise and the pauses, the silence contemplation. Instigates to listen to what still resonates in the city from submerged layers stories, a proposal that makes visible the dislocating potency of art.
\end{abstract}

Keywords: Memory. Art. City. Performance. Florianópolis.

${ }^{1}$ Doutoranda pelo Programa de Pós-Graduação em Psicologia da Universidade Federal de Santa Catarina (UFSC). mariana.zabot@gmail.com

2 Professora titular aposentada da UFSC. avzanella@gmail.com

${ }^{3}$ Profa. Dra. Titular da Universidade Federal do Rio Grande do Sul (UFRGS), docente e pesquisadora do Programa de Pós-Graduação em Psicologia Social e Institucional. mariana.zabot@gmail.com 
A participação da primeira autora deste texto em uma performance realizada em uma avenida na região central de Florianópolis (SC) provocou esta escrita, a qual tem como foco a problematização das tensões entre passado e presente, memória e esquecimento produzidos pela performance. Experimentar a cidade a partir da arte e a abertura possível que ela pode conferir à produção de uma relação estética com o espaço urbano, configurou-se como condição para uma leitura outra do território específico da cidade onde se deu a intervenção, para a visibilização de nuances pouco conhecidas que narram histórias outras sobre o lugar, quem o habitava e os modos de vida que constituíam o cotidiano da cidade em tempos remotos.

Trata-se da performance Parte da Paisagem ${ }^{4}$, que teve ações performadas por Karin Serafin ${ }^{5}$, concebidas em parceria com o diretor de teatro Renato Turnes ${ }^{6}$. As ações aconteceram em cinco pontos distintos da Avenida Hercílio Luz, no centro da cidade, e contaram também com intervenções compartilhadas com outros artistas ${ }^{7}$, sendo eles Camila Petersen, Daniele Zacarão, Gabriel Vanini, Pedro Franz e Rica de Lucca. Esses artistas foram incumbidos da tarefa de deixar rastros da intervenção na paisagem urbana onde a mesma ocorreu.

O convite para o evento foi divulgado através da rede social Facebook. A proposta de refletir sobre memória e espaço urbano convocava pessoas para participarem da intervenção, sendo informado que outra parte do público seria composta pelos transeuntes de passagem pela avenida.

No dia marcado, as pessoas interessadas compareceram ao local informado. Era meio-dia e meia de uma sexta-feira quando o grupo se reuniu na calçada da Avenida Hercílio Luz , próximo da Praça Olívio Amorim, no centro de Florianópolis. Pessoas vindas de diferentes direções iam ao encontro do único grupo de pessoas

${ }^{4}$ Projeto vencedor do Prêmio Edital Elisabete Anderle de Estímulo à Cultura - 2014.

${ }^{5}$ Karin Serafin é artista, dançarina, performer, integrante do grupo de dança "Cena 11".

${ }^{6}$ Renato Turnes é diretor de teatro no "Coletivo La Vaca".

Os trabalhos desses artistas podem ser vistos na página do projeto "Parte da paisagem": https://www.facebook.com/partedapaisagem/.

${ }^{8}$ Avenida com 1,4km extensão no centro de Florianópolis. 
que permanecia parado e interagindo entre si, naquele costumeiro horário do centro de uma cidade em que os passos guiam-se pela pressa da saída ou retorno ao trabalho. Esperando por algo que iria acontecer a qualquer instante, mas que não se sabia ao certo de que forma, o grupo recebeu uma última integrante. Todos perceberam que estavam esperando por essa pessoa e que a tarefa era deixar-se levar por ela naquela avenida. A performer distribuiu, então, copos de vidro e, em seguida, deixou uma mensagem escrita com um giz sob a calçada: "Se tudo ficasse quieto conseguiríamos escutar o rio?” (Figura1).

Figura 1- Mensagem escrita pela performer. Foto: Mariana Zabot Pasqualotto

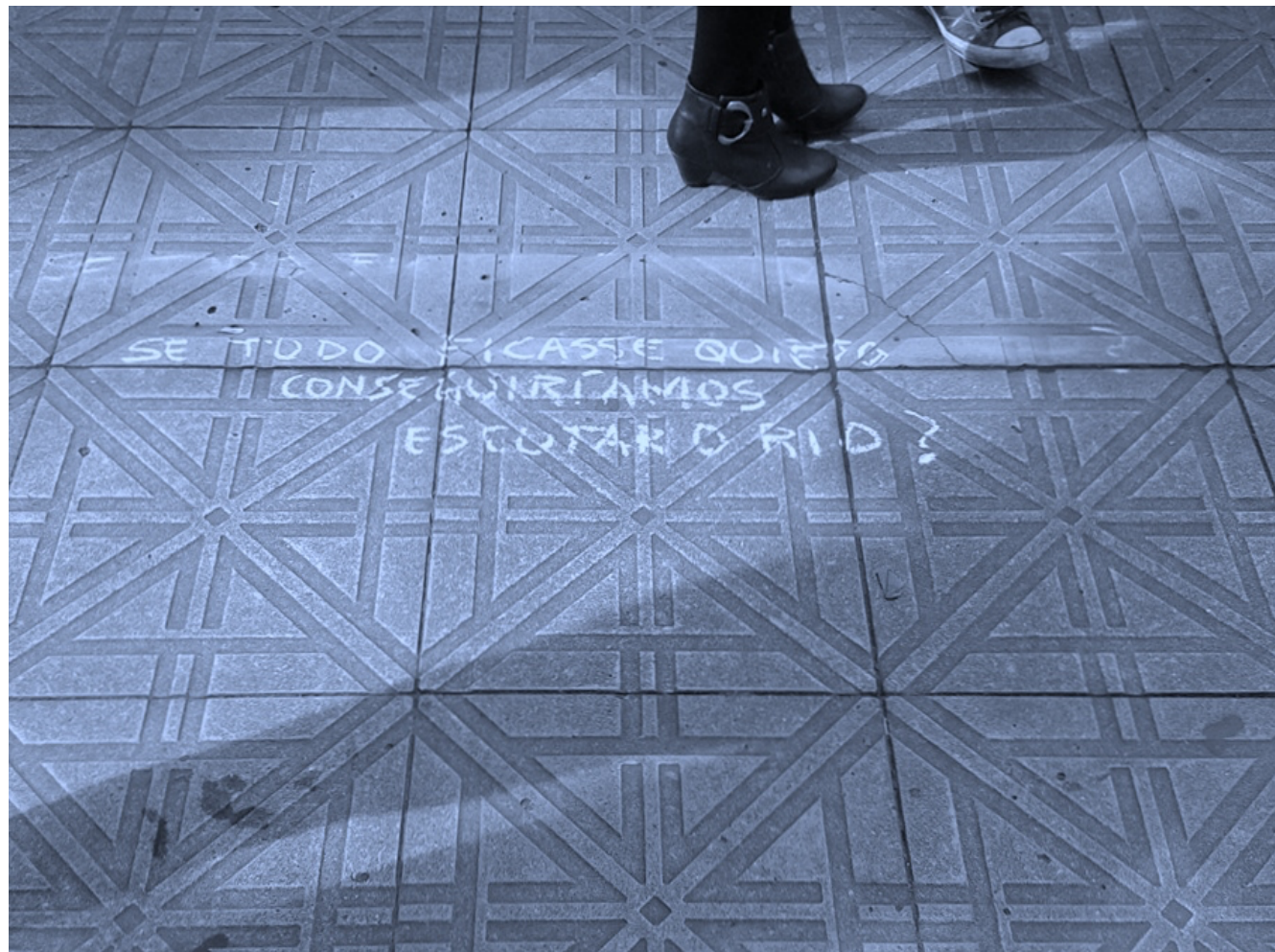

Estávamos em uma calçada, ao centro de um bulevar, e cercados por muitos prédios e construções. Um convite então nos foi feito sob a forma de uma nova mensagem escrita na calçada: "Tempo para ouvir o rio". Aceitamos, e passamos a acreditar que um som quase imperceptível diante do barulho da vida urbana poderia ser ouvido. 
O rio ganhava vida à medida que histórias da população que habitava suas margens nos eram contadas: tratava-se do Rio da Bulha, apelido dado ao córrego Fonte Grande onde, às suas margens, residiu, a partir da segunda metade do século XIX até início do século XX, em cortiços e "casinhas", a população de baixo poder aquisitivo, a saber, "mestiços e negros livres, viúvas, soldados, lavadeiras e as "marafonas" que em geral viviam de aluguel" (Santos, 2009, p. 89). Essas pessoas passaram a viver nesse lugar em decorrência do crescimento populacional, depois que o local onde residiam, próximo ao porto, passou a ser ocupado por comerciantes. Sabe-se que o rio foi canalizado em 1922 e completamente apagado do cenário urbano em 2008 por uma cobertura de concreto que transformou sua antiga presença em um bulevar.

Após "escutarmos" o rio, fomos levados pela performer, em um trajeto pela Avenida Hercílio Luz, a entrar em contato com histórias sobre o mesmo e a população que o margeava, assim como histórias de tempos outros do centro urbano, todas elas baseadas na pesquisa realizada pela artista na Casa da Memória9 e a partir da escuta de histórias orais da região. As histórias tratavam, por exemplo, sobre o fato do Rio da Bulha ser reconhecido como um "rio seco", já que mesmo nas épocas de fortes chuvas, suas águas não subiam o suficiente. No rio, também nos foi contado, era permitido lavar roupas, prática comum das lavadeiras que ali lavavam as vestimentas de seus patrões e, também, banhar-se (ao contrário do mar, que se localizava muito próximo dessa região, mas era de acesso proibido para banho, muito provavelmente por ser um local de depósito de lixo da população(10).

Durante o trajeto pela avenida, paramos defronte a alguns estabelecimentos e testemunhamos outras ações da artista Karin Serafin, que performava histórias sobre os locais, por exemplo em frente ao Clube 12 de Agosto (1872)11, que ficou

9 Centro de documentação da vida social e cultural do município de Florianópolis.

10 De acordo com o "Código de posturas" de Florianópolis do ano de 1845, as práticas de despejo de lixo e excrementos no mar eram comuns. O código ainda estabelecia que além dos excrementos que costumavam ser levados dentro de potes pelos escravos até o mar, também as águas das roupas lavadas do Hospital de Caridade e os restos do pescado do mercado fossem jogados ao mar todos os dias. (Santos, 2009).

11 Fundado em 1872, o Clube 12 de Agosto fazia parte dos clubes frequentados pelas elites locais, militares e 
conhecido na região especialmente pela promoção de muitos bailes de debutantes, e no Oscar Hotel (1960)12, um conhecido hotel da região.

A artista também nos apontava, em suas intervenções, alguns detalhes muitas vezes imperceptíveis ou desconhecidos para grande parte dos transeuntes daquela avenida, como uma série de prédios que se localizavam ao lado uns dos outros e que levavam nomes de mulheres. Todas as histórias, coincidências e os mistérios que nos eram narrados, tratavam-se de nuances invisibilizadas, desconhecidas ou insignificantes para os usos que se deram à região, e para a aceleração que tomou conta do cotidiano daquele espaço.

Por último, chegamos ao terraço de um hotel onde o fechamento da intervenção urbana ocorreu. Nele nos deparamos com a possibilidade de tensionar paisagens de tempos vários, através de monóculos (Figura 2). Espiamos imagens antigas da cidade ao mesmo tempo em que tínhamos à nossa frente uma vista privilegiada do centro urbano.

A performance assim encerrou, com seu público no alto do prédio observando, através de monóculos, cenas de um tempo outro, enquanto a performer que nos conduziu por todo o trajeto através de uma narrativa poética e sensível às histórias que podem compor um espaço como o centro urbano desceu o prédio e, vestida de debutante, figurino relacionado às histórias do clube, misturou-se à paisagem das ruas do centro da cidade. Sobre essa cena final, ficou registrada a ideia de que certas memórias como as que se relacionam às histórias contadas na intervenção continuam a circular, mesmo que de forma espectral, por entre os corpos da cidade. A referência, aqui, é a "uma história fantasmal", como nos diz Didi-Huberman (2013, p. 35), no sentido de que nela o arquivo é considerado um vestígio material do rumor dos mortos. Trata-se de vir a saber o

funcionários públicos, embora alguns trabalhadores participassem das festas ou como sócios do local. (Schmitt, 2000).

12 Fundado em 1960 o Oscar Hotel, assim como outros hotéis da época, recebia principalmente políticos do interior, executivos engenheiros de empreiteiras, e, em determinados períodos do ano, recebia aos professores, estudantes e funcionários da Universidade Federal de Santa Catarina, além de representantes comerciais. (Santos, 2008). 
que sobrevive, no presente, de uma população de fantasmas, cujos traços mal são visíveis, porém se disseminam por toda parte.

Figura 2 - Imagem reproduzida no monóculo e ao fundo paisagem do centro de Florianópolis. Foto: Mariana Zabot Pasqualotto

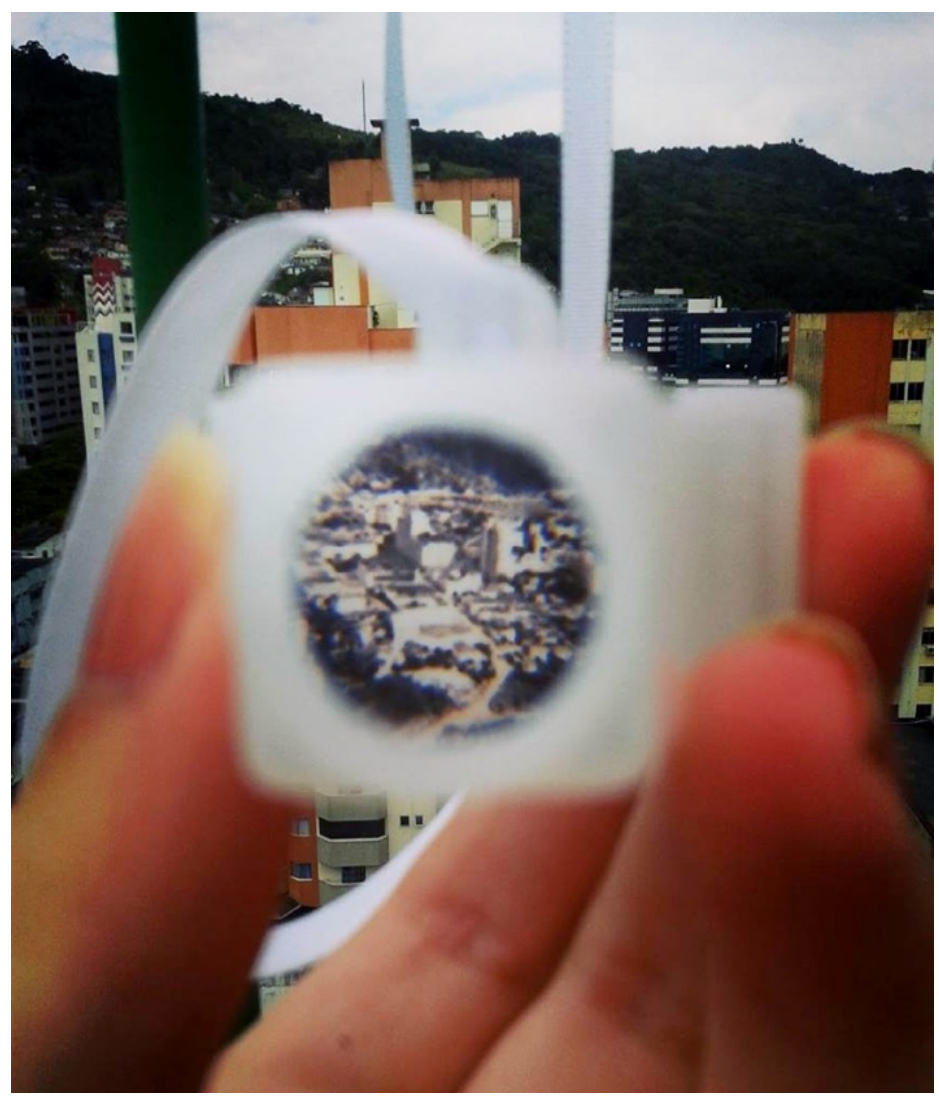

Com a narrativa da escuta do rio e do trajeto que se fez na avenida onde o mesmo foi encoberto, ilustra-se de forma simbólica a escuta de memórias submersas, o olhar voltado aos rastros apagados da cidade. Eis as questões provocadas pela performance que nos levam aos passos seguintes desta narrativa, a saber, a contextualização histórica do local e a problematização das tensões entre passado e presente, memória e esquecimento produzidos pela performance. 


\section{Os ruídos de um rio}

O bairro Pedreira que margeava o rio da Bulha era considerado, conforme Santos (2009), "o bairro mais sujo da cidade" e foi um dos lugares onde apareceram os primeiros casos de epidemias em Florianópolis. "Cortiços baratos e sem conforto. Lavadeiras. Marinheiros. Soldados. Mendigos. Gente de má fama. Toda uma favela a marginar um rio imundo" (Cabral, 1971, p. 193 apud Santos, 2009), essa era a descrição da população que se encontrava à margem do rio e à margem da sociedade dos séculos XIX e XX em Florianópolis ${ }^{13}$. Também se encontra uma descrição dessa mesma região no seguinte trecho:

[...] com uma feição rotineira colonial, com suas ruas estreitas, com inúmeros casebres a enfeiar-lhe a estética, Florianópolis impressionava mal ao forasteiro. O Beco Irmão Joaquim com seus cortiços margeando o canal da Fonte da Bulha até a Pedreira, era um verdadeiro foco de miasmas e um conhecido foco de vadiagem. Não havia ali a menor noção de higiene. Os casebres não tinham instalação de esgotos. [...]. Quilômetros assim, rumando o leito da Fonte da Bulha, a mesma prática dos moradores pobres, sem noção da limpeza e dos bons ensinamentos da higiene". ("Remodelação de Florianópolis. República, 1 de fevereiro de 1920, página 1. (BPESC), como citado por Santos, 2009).

Com essas condições de vida, coube a esse lugar receber da elite urbana o apelido de Rio da Bulha (Santos, 2009). Se recorrermos ao dicionário ${ }^{14}$, "Bulha” quer dizer "Confusão de ruídos, de gritos; barulho, gritaria. Estrondo, estampido. Desordem, desavença, motim. Fazer bulha com, atribuir grande importância a alguma coisa, alardeá-la”. Naquele contexto histórico, a população que vivia à margem do rio, com suas condições, hábitos e costumes próprios, fazia ruído aos ideais de urbanização, destoava do projeto de transformação da cidade e trazia “má impressão" aos olhos dos forasteiros que ali chegavam.

${ }^{13}$ Até o início do século XVIII, Florianópolis, chamada de "Nossa Senhora do Desterro", era habitada por índios guaranis que foram expulsos da ilha com a chegada da primeira população estrangeira. Segundo Santos (2009, p. 35), "A população da pequena póvoa foi formada por portugueses e outros europeus náufragos, desertores, fugitivos ou desterrados condenados ou abandonados, outros eram colonos bandeirantes vicentistas com seus índios escravos ou agregados e os escravos africanos e filhos nascidos aqui".

14 Dicionário online de Português. (https://www.dicio.com.br). 
Sobre o ideal de urbanização do século XX em Florianópolis, Santos (2009, p. 505) explica que:

\begin{abstract}
Em 1918, quando assumiu o cargo de governador, Hercílio Luz iniciou, com a superintendência municipal de João de Oliveira Carvalho, um programa de remodelação de Florianópolis: abertura de novas ruas; construção de edifícios públicos e um grande projeto de saneamento, cuja maior obra era a canalização total do Rio da Bulha, além da construção da Avenida do Saneamento em suas margens e demolição dos cortiços. O governo transformaria a várzea da "Bulha" em uma área valorizada de interesse do Estado e da classe rica.
\end{abstract}

A Avenida do Saneamento, atual Hercílio Luz, foi inaugurada em 1922, e as práticas sanitaristas consequentemente implicaram na retirada da população menos favorecida que residia naquela região. No bairro Pedreira, casas foram demolidas para abertura da Avenida e também para fins "estéticos", assim a exigência da construção de novas casas dentro do padrão imposto pelas regras municipais fez com que a população, que não tinha como arcar financeiramente com as despesas para isso, começasse a ocupar massivamente os morros (Santos, 2009). Novas transformações nesse espaço começaram a ser feitas em 1990, quando foi coberto metade do canal, e assim permaneceu até que no final de 2008 ele foi completamente fechado.

Neste ponto, ocorre-nos começar a explorar o olhar que construímos a essa experiência estética com foco nos restos de memórias de uma população que um dia se quis apagar do cenário urbano. Por isso, podemos pensar de início que a visão de sujeito que guia nossa compreensão acerca dos diferentes atores sociais que estão entrelaçadas à história do Rio da Bulha e à performance, pauta-se na compreensão de uma relação inexorável que se estabelece entre sujeito e sociedade, noção desenvolvida por Vygotsky (Zanella, 2004). Para Zanella, isso significa dizer que: "Só há sujeito porque constituído em contextos sociais, os quais, por sua vez, resultam da ação concreta de homens que coletivamente organizam o seu próprio viver." (2004, p. 127).

Colocamos em diálogo essa visão de sujeito com o conceito de história presente na tese 7 de Walter Benjamin (1994), na qual o autor destaca que os que num momento histórico dado dominam são os herdeiros de todos os que 
venceram antes, levando-nos à crítica ao historiador "empático" com o polo dos vencedores. Em tal perspectiva, os narradores críticos e que produzem a história a contrapelo reconhecem os bens culturais como despojos de uma luta, de um jogo de forças, sendo que se perguntar por sua origem não se daria sem o horror das revelações.

É emblemática a frase de Benjamin (1994, p. 225) que ressoa convenientemente no contexto dessas nossas análises: "Nunca houve um monumento da cultura que não fosse também um monumento à barbárie”. Se a cultura não é isenta de barbárie, diz-nos ainda, não o é, tampouco, o processo de sua transmissão. Nada do que um dia aconteceu pode ser perdido para a história (Benjamin, 1994, p. 223), e o passado, com seu índice misterioso que assombra e acompanha nossos dias, só se deixa captar como imagem veloz e relampejante, não sendo possível conhecê-lo como ele de fato foi. Mas, torna-se importante considerar que, segundo nos informa a tese 6 (Benjamin,1994, p. 224), "o dom de despertar no passado as centelhas da esperança é privilégio exclusivo do historiador convencido de que também os mortos não estarão em segurança se o inimigo vencer". De certo modo, a performance Parte da Paisagem contribuiu para a escuta e visibilização de alguns desses mortos ao escavar memórias esquecidas da cidade.

\section{Cidade, memória e arte}

Considera-se que a intervenção urbana Parte da Paisagem, realizada por Karin Serafin, Renato Turnes e os demais artistas convidados, possibilitou experienciar o subsolo das memórias urbanas daquela região da cidade, tensionando o olhar entre cenas de diferentes tempos. Ela também abriu a possibilidade de ampliar experiências individuais com a cidade através de um convite à produção de novos olhares e sentidos para o local da avenida, tanto para aqueles que participavam da performance, convocados pelo convite online, quanto àqueles que se depararam em meio ao seu percurso no centro da cidade ou que saiam de seus estabelecimentos para, de alguma forma, participar observando, perguntando o 
que o grupo estava fazendo naquele local, ou até incomodando-se com aquela ação.

Sobre a forma como a proposta da performance foi concebida, podemos pensar que ela não tratou das memórias que fazem parte da história oficial da cidade, dos seus "heróis", e do digno de ser mostrado, ou seja, histórias clássicas que correm o risco de pouco tensionarem o presente, como lembra Bakhtin (2003) ao citar "Viagem à Itália”, de Goethe. Segundo Bakhtin, Goethe nos aponta um caminho - um desvio para o olhar que procura mais que uma evocação supérflua de um passado exaltado; um caminho metodológico para o pesquisador que se interessa pelas histórias invisibilizadas de uma cidade, que pode ser observado no seguinte trecho:

O guia ficou ainda mais surpreso quando Goethe, "indiferente às lembranças clássicas", passou a juntar cuidadosamente umas pedrinhas na beira do rio. "Mais uma vez, não consegui the explicar que não há forma mais rápida de obter uma ideia de uma região montanhosa do que examinar os tipos de rochas arrastadas pelos riachos, e que se tratava ali também de, por intermédio de resquícios, adquirir uma noção daqueles píncaros eternamente clássicos da antiguidade da terra." (Bakhtin, 2003, p.234).

Vemos assim que Goethe propõe um olhar às insignificâncias - juntar as pedrinhas na beira de um rio - como forma de se aproximar de um passado; ensina que os laços com o mesmo são feitos de forma concreta, ou seja, a partir dos resquícios dos tempos é que se pode constituir a ideia de um todo ao qual se procura conhecer. O convite feito durante a intervenção urbana para ouvir o rio da mesma forma instiga o olhar ao insignificante, ao esquecido; propõe tensionar passado e presente, o aceleramento, o barulho e a parada, a contemplação do silenciado, e se configurou como uma das formas possíveis de se estabelecer uma relação concreta com o passado daquela região central da cidade.

Sobre a ideia de contemplar o que estava silenciado historicamente e geograficamente, podemos pensar, a partir de Hissa e Melo, que a aceleração característica do cotidiano citadino faz com que nosso olhar veja sempre o mesmo, nada além da presença de um mesmo tipo de experiência. Esses autores nos dizem: 
A aceleração habita a casa dos tempos, da qual parece desejar-se única proprietária. A cidade contemporânea contém maior efemeridade, movendo-se em alta velocidade, registrando e apagando rapidamente o que passou. Mas sempre nos inscrevemos no espaço - espaço sobre espaço, história sobre história, escrita sobre escrita [grifo dos autores] [...]. (Hissa e Melo, 2013, p. 71).

Pensamos a partir disso que a cidade se urbaniza, acelera ritmos e passos dos seus transeuntes, apaga rastros de existências e redesenha continuamente novos modos de habitar o espaço urbano. Sobre os rastros, não somente os materiais são destruídos por não fazerem mais parte dos interesses que movem a cidade, mas, também, rastros de existências da vida ordinária - das relações e costumes - de um tempo passado deixam de interagir com a paisagem urbana.

No caso do Rio da Bulha, vemos que a falta de canalização e o esgoto ao ar livre passam a fazer parte do uso de estratégias para atender rapidamente à intenção de higienização e embelezamento urbano do local. Processo esse que tem início quando a essa região em que residiam lavadeiras, negros e pobres é atribuído o apelido de "bulha", expressão para referir-se às pessoas "sem noção de higiene". Todos esses acontecimentos estão tramados ao processo de gentrificação dessa região.

Nessa aceleração que provoca o apagamento, como dizem os autores, onde vestígios permanecem invisibilizados, em que algo se cala, torna-se insignificante, rastros e restos, a proposta de uma intervenção estética, por exemplo, provoca o tensionamento de diferentes vozes sociais, abre a possibilidade de leitura dos rastros possíveis de serem encontrados - como uma imagem, um testemunho, configurações cotidianas, ou marcas num espaço.

Na intervenção urbana Parte da paisagem, a proposta fazia com que o cenário onde se inscreveram muitas histórias, apagado pela vontade humana que seguia certos ideais de uma época, passasse a ser tensionado no presente. Por mais que os barulhos da correnteza e das vozes já não pudessem mais ser ouvidos, os restos de um passado tiveram lugar na imaginação, possibilitando uma revivescência, um after life, ou ainda, imagens de sobrevivência. Sobre essas imagens entendemos que: 
Atrás de cada coisa em dissolução coexistem imagens pacientes à espera de virem a ser despertadas, imagens que nos permitirão reaver o objeto perdido, agora inatual e inapreensível envolto que se acha em um jogo de espelhos disputado sobre uma ponte enevoada e trêmula que nos transporta em nosso agora para o longínquo do outrora (Benjamin, 1994; Didi-Huberman, 1988; 2015). O objeto perdido, aparecendo na qualidade de desaparecido, tem sua imagem anunciando o retorno do que não volta, mesmo que o que ela faça aflorar ainda tivesse the pertencido, caracterizando-se como sua qualidade, tendo-lhe sido, pois, imanente e habitando-o como seu coração singular e único. (Fonseca, 2018, p. 263).

As imagens de sobrevivência, efeito da tenacidade das marcas e rastros do passado, ressurgem como tênues e espectrais, compondo o que podemos chamar de "espírito do lugar", daquilo que ele foi um dia, está sendo e será. Dizer "espírito", aqui, contempla a ideia de um nó problemático original fundante que nunca será recuperado em sua totalidade, mas que se oferece a revelações parciais que não se traduzem como captura das causas originais. O nó problemático que anima sub-repticiamente as cidades e seus específicos lugares de recordação refere-se ao plano de potências que the é imanente, e cujo desenvolvimento ou atualização se dá aos poucos, sob a luz daquele tempo presente em que é considerado. Sempre sendo, o "espírito" de um lugar se metamorfoseia e se conserva ao mesmo tempo, evidenciando as variações e as multiplicidades que foram conjuradas no ato de sua fundação.

A performance artística ofereceu-se como dispositivo ao olhar e operou, como nos diria Didi-Huberman (2017, p. 14), "o próprio olho da história”, buscando rasgar os véus tecidos pelo esquecimento e pela indiferença cotidiana. Os transeuntes distraídos e mesmo os intencionalmente presentes puderem ver-se bifurcados em um repente, situando-se enredados no movimento de gestos de um levante que se tornou coletivo à medida que movimentou a presença de ausências, de desaparecimentos, topologias, objetos e populações revelando-os sempre no cruzamento com vidas e com modos de viver marcados pelos entrecruzamentos de instâncias históricas heterogêneas e sobredeterminadas. Poder-se-ia pensar que a performance artística enquanto narrativa histórica foi sustentada pela recusa de desvincular as imagens produzidas de seus laços com a dramática encenada por uma multidão de sujeitos infames que atuaram naquele 
palco/território existencial. Retirar-lhe esse contágio com tais movimentos vitais e antropológicos seria retirar-lhe seu próprio sangue. Falamos, aqui, da marca da indestrutibilidade do tempo e da tenacidade das sobrevivências que, segundo DidiHuberman (2013, p. 47) pode ser comparada a "um rio que, havendo escavado um leito para si, correria nele por séculos”.

Não se pode, entretanto, exprimir tal "permanência da cultura" como sendo uma essência, mas ao contrário, como um sintoma, um traço de exceção, uma coisa deslocada (Didi-Huberman, 2013, p. 47). E, ainda, devemos considerar que o que sobrevive, não sobrevive triunfalmente tal como apregoado por Spencer ${ }^{15} \mathrm{em}$ seu evolucionismo social: a vitória do mais apto. A sobrevivência se dá em relação à própria morte e sempre se manifesta ou expressa em termos sintomais e fantasmais: "desaparece num ponto da história, reaparece muito mais tarde, num momento em que talvez não fosse esperada, tendo sobrevivido, por conseguinte, no limbo ainda mal definido de uma memória coletiva." (Didi-Huberman, 2013, p. $55)$.

As ações da performer provocaram estranhamento ao visibilizarem a existência do rio no subterrâneo da grande avenida e seu bulevar. Além disso, tal ação deixou marcas destinadas ao futuro, em quem a experienciou ou a estranhou, ou nos vestígios deixados sob o seu percurso pelos artistas. Mais do que ouvir uma correnteza, pôde-se ouvir correntezas de memórias submersas pelo processo de urbanização da cidade: foi possível conhecer o inaudivel, o som da "bulha" que compunha a polifonia urbana.

A experiência da intervenção urbana Parte da paisagem, como um "olho da história", propiciou uma disparidade na ordem dos dias e do pensamento, afetou os corpos pelo que não sabiam de estranhos e longínquos modos de vida cujos restos perduram na tessitura da cidade, forçou o pensamento a considerar o tempo da história e a história dos tempos, desmontando e mesmo descontruindo algo das percepções clichês e automatizadas a respeito da cidade e de seu cotidiano.

15 Herbert Spencer (1820-1903), filósofo inglês, representante do liberalismo clássico, fundador da teoria do darwinismo social. 
Cabe sublinhar, nesse caso, que estamos analisando o curioso caminho escolhido para narrar a história a contrapelo: o caminho da estética aparece como expressão da crença de que todo o pensamento emerge do corpo e de suas afecções. Aqui, estamos diante de uma poética que é feita para produzir um conhecimento distante dos racionalismos e funcionalismos. Conhecimento implicado à vida dos sujeitos experimentada em meio a lutas discursivas que convulsionaram tanto o plano da política quanto o das ciências e técnicas e da cidade. O movimento higienizador e racionalista, apregoado em nome de padrões civilizatórios, acabou por soterrar aquilo que considerava, sob seus valores, como barbárie, operando o deslocamento de segmentos da população considerados como não portadores dos valores da identidade hegemônica e politicamente dominante.

Sobre isso, podemos usar como exemplo a arte realizada pelas "tejedoras de Mampuján”, mulheres que realizam desde 2016 um trabalho coletivo costurando desenhos feitos a partir de retalhos de tecidos em uma manta (técnica conhecida como quilt, ou tela sobre tela) e narrando assim suas experiências com o conflito armado que ocorreu no ano 2000 no município onde moram, em Mampujàn, na Colômbia. Aqui também a arte - como caminho estético - é usada como aposta para a reconstrução de uma memória histórica, contada pelas vítimas do acontecimento.

Tanto na criação estética das mulheres “tejedoras de Mampuján” quanto na performance urbana "Parte da paisagem", temos a potência deslocadora da arte, agindo e sendo operada como narrativa histórica fundada no pressuposto de uma montagem de memórias. A performance, por sua vez, lançou no cotidiano atual da cidade uma espécie de aviso de incêndio em relação ao passado que se encontra ali pisado e soterrado, esquecido, mas que nem por isso deixa de relembrar e dar a ver as ressonâncias das ações e práticas governamentais que agiram como silenciamento e "concretação" de fluxos e fluidos, em nome de ideais civilizatórios e sobretudo moralizantes. Modos de construir cidades, modos de governar populações e distribui-las no espaço territorial segundo seu valor simbólico e cultural. 
Intervenções estéticas que fazem desdobrar uma "poética-ética - da memória" (Seligmann-Silva, 2016), como a intervenção sobre a história do som da bulha, configuram-se como ações políticas em determinados espaços. De acordo com Rancière, "A atividade política é a que desloca um corpo de um lugar que the era designado ou muda a destinação de um lugar; ela faz ver o que não cabia ser visto, faz ouvir um discurso ali onde só tinha lugar o barulho, faz ouvir como discurso o que só era ouvido como barulho" (Rancière, 1996, p. 42), e muito próximo disso se configuram possibilidades outras de vivenciar o espaço urbano, possibilidades que promovam rupturas nos olhares cegos à história e às camadas de memórias da cidade.

Experiências contemporâneas com o passado, através de intervenções artísticas, parecem produzir novos rastros, ou vestígios contemporâneos do passado, rastros que ressurgem em meio à experiência da (re) construção de uma narrativa. São experiências possíveis com as histórias encobertas pelas camadas dos tempos de uma cidade, ficções criadas como forma de ainda podermos escutar as vozes do passado.

Tais ações desejam operar como gestos de levante frente ao enfraquecimento do olhar e sua perda crítica. Nesse sentido, operam como luzes intermitentes no cenário urbano, podendo ser apontadas como pequenos vagalumes em revoada na noite: operam em bando, produzem certa luminosidade ali onde há trevas, são portadores de efemeridade e intermitência, não podendo vir a ser comparadas às experiências rememorativas e comemorativas dos atos oficiais das autoridades públicas.

O valor inusitado e causador de estranhamento da experiência que temos em foco neste texto refere-se ao fato da mesma ser impulsionada pelo desejo de visibilizar o que se tornou invisível e esquecido do ponto de vista das populações rejeitadas e excluídas. Aqui, não são as ações implementadas pelo poder público que se tornam objeto de discussão, de escuta e de olhar. Elas comparecem de uma forma um tanto oblíqua, quando se faz falar as memórias dos "desterrados" e "deslocados". Comparecem como correspondências de como sua violenta presença se dá através daquilo que foi silenciado e estancado em seu fluxo vital. 
Para dar feições civilizadas e de boa forma e aparência à emergente capital, tornou-se necessária uma sequência de atos que atestam, acima de tudo, a conflitualidade entre sociedade e poder público. Restaria ainda lembrar que o caso que aqui nos ocupa não passa de mais um no conjunto de nossas cidades e capitais. Trata-se, mesmo, de um exemplo de práticas muito recorrentes em nosso país, práticas carregadas de violência simbólica e autoritarismo.

A essa discussão cabe trazer o desenvolvimento de uma estética que ficou conhecida como antimonumento e que surge, segundo Seligmann-Silva, em resposta à tradição da construção dos monumentos, ligada à comemoração de vitórias bélicas. O antimonumento,

de certa maneira, funde a tradição do monumento com a da comemoração fúnebre. Desse modo, o sentido heroico do monumento é totalmente modificado e deslocado para um local de lembrança (na chave da admoestação) da violência e de homenagem aos mortos. Os antimonumentos, na medida em que se voltam aos mortos, injetam uma nova visão da história na cena da comemoração pública e, ao mesmo tempo, restituem práticas antiquíssimas de comemoração e rituais de culto aos mortos. (Seligmann-Silva, 2016, p. 50).

Ainda para Seligmann-Silva, no antimonumento está "a própria ideia de realizar uma obra que novamente "des-obra" nosso processo de enterramento do passado" (Seligmann-Silva, 2016, p. 53). Os rastros que ressurgem no contemporâneo da cidade através da arte, como na estética do antimonumento, produzem tensionamentos que nos convidam a aprofundar olhares a esse campo, a pensar como o passado presentifica-se em constante confronto, e de que forma resistem seus rastros no cotidiano da cidade.

Neste ponto, não podemos deixar de associar a experimentação performática em questão como parte de um luto. Lembrar e esquecer conjugam-se nas dobras da narrativa que é encenada e performatizada. Sabe-se que para redimir fantasmas, há que se lhes dar voz e deixá-los passar. Fantasmas e espectros vivem no presente de nossas visões atuais, operam como companhias anacrônicas ao nosso lado. São presenças tênues e apagadas, vivem nas franjas dos sonhos e dos momentos distraídos, têm o hábito de irromperem no cotidiano como 
relâmpagos em momentos de perigo, querem ganhar passagem e expressão, advém daquilo que se encontra encarcerado e recalcado nas camadas da mente individual e coletiva. Sobrevivem como restos, como parcialidades desprendidas de seus contextos anteriores e longínquos. Soltos e vagantes, os elementos das lembranças tornam-se como contas de um rosário arrebentado, livres para habitar outras constelações de sentido e fazerem parte de novas conformações. É assim que o passado desaparecido retorna como composição diferencial do presente. Faz-se diferente do que foi à medida que seus elementos se veem reordenados nos discursos e dispositivos de uma outra época, de uma outra lógica e de uma outra cultura. Trata-se de uma sobrevivência do passado que sendo vista sob os olhos do presente, ou seja, a partir dos atuais regimes de visibilidade e dizibilidade, possibilita um maior ou menor grau de revelações e sentidos daquilo que aconteceu. Tal sobrevivência, advinda da narração histórica, possibilita a ressureição do passado ou de algo dele apenas como interpretações e sentidos concretizadas a partir do presente em que ele é apreendido.

Quando falamos em memória, é importante frisar que a mesma seja considerada como processualidade e devir. Não se trata da adoção de uma posição historicista e cronologizada, afeita a datas que se colocam em uma sequência linear e cumulativa em direção a um progresso ou a um declínio. Tampouco implica considerar o passado como reservatório de modelos eternos a seguir e a conservar e o futuro como ideia de superação e síntese final. Nem passado nem futuro regem a orientação que aqui se delineia. Trata-se, antes, de uma abordagem da história do próprio presente considerado espesso e composto tanto pelo passado quanto pelo futuro, tempo que opera como um nó problemático de entretempos no qual estamos envoltos. Se falássemos como Walter Benjamin no texto de 1940, “As teses sobre o conceito de história”, diríamos que a história é objeto de uma construção cujo lugar não é o tempo homogêneo e vazio, mas um tempo saturado de "agoras". Benjamin postula que nenhum fato, por ser causa, torna-se histórico. Segundo o filósofo, ele se transforma em histórico postumamente, graças a acontecimentos que podem dele estar separados por milênios. Cabe àquele que quer conhecer a história de seu presente 
no sentido profundo, captar a configuração em que sua própria época entrou em contato com uma outra, anterior e determinada. É nesse sentido que o presente ganha o sentido de agora.

Assim, a partir de Benjamin (2012), entendemos que a memória é um processo que está em contínua formação e se dá em relação inseparável com o passado e com o futuro; o passado, portanto, perpassa a condição de (re) configuração que se dá no presente por meio dos elementos que perduram como vestígios. Dessa forma, tais vestígios dos tempos e dos acontecimentos que resistem no presente nos permitem "descortinar o 'Agora' " que se oferece ao nosso conhecimento (Barrento, 2013).

Na performance Parte da paisagem, na medida em que se narravam histórias "apagadas" pela urbanização da cidade, ficava à critério do público participante imaginar seu contexto e suas relações, experimentar um tempo passado que se atualizava naquele agora. Na (re)construção da narrativa sobre uma "população à margem" - à margem do rio, à margem da economia da época, à margem das memórias valorizadas - tensionar o apagamento de suas histórias através da arte é também uma forma de compreender a relação inseparável entre memória e esquecimento.

Seligmann-Silva diz que “a memória não é apenas um "bem”, mas encerra ainda uma carga espectral que gostaríamos muitas vezes de esquecer, ou enterrar, da maneira como fazemos com nossos mortos" (2016, p. 50). As memórias produzidas na cidade, portanto, estão amalgamadas às condições de (in)visibilidades que se relacionam aos aspectos sociais de cada época. Toda cidade, nesse sentido, possui seus "rios do esquecimento".

Na discussão sobre o esquecimento e seus rios, lembramos do mítico rio do esquecimento, chamado Lete, que compõe um dos primeiros mitos gregos, e cujo nome dá origem à "letotécnica", uma das palavras ${ }^{16}$ que significam "a arte do esquecimento" (Weinrich, 2001). O rio é assim chamado por causa da divindade feminina Letes que forma par contrastante com Mnemosine, a deusa da memória.

${ }^{16}$ Outra palavra que liga a esse significado é "amnestônica”, que provém das palavras amnésia, esquecimento. 
Na interpretação, o mito "Lete”

[...] é sobretudo nome de um rio do submundo, que confere esquecimento às almas dos mortos. Nessa imagem e campo de imagens o esquecimento está inteiramente mergulhado no elemento líquido das águas. Há um profundo sentido no simbolismo dessas águas mágicas. Em seu macio fluir desfazem-se os contornos duros da lembrança da realidade, e assim são liquidados. (Weinrich, 2001, p. 24).

Se recorrermos à palavra grega Aletheia, que significa "verdade" e é central no pensamento dos filósofos gregos, veremos que parte de sua composição Leth - quer dizer "oculto", "encoberto". Assim Leth, negado pelo prefixo "a”, dá a entender que a verdade era o que não estava oculto, nem encoberto. Aletheia carregava a ideia de "verdade" como algo inesquecível, não encoberto, não oculto, e não latente (Weinrich, 2001).

Isso diz muito sobre a forma como se desenvolveu o entendimento sobre o esquecimento em contraste com o que se entendia por "verdade". Para Weinrich (2001, p. 21), "por muitos séculos o pensamento filosófico da Europa, seguindo os gregos, procurou a verdade do lado do não esquecer, portanto da memória e da lembrança, e só nos tempos modernos tentou mais ou menos timidamente atribuir também ao esquecimento uma certa verdade”.

Esses rastros iniciais da forma como a história da humanidade vieram atribuindo sentidos ao esquecimento demonstram a existência de uma "cultura do esquecimento" (tardiamente reconhecida) que atravessa as camadas dos tempos e tensiona toda a forma como se organizam as memórias de uma sociedade. Voltando-nos, assim, ao plano da narrativa, vemos que não podemos deixar de considerá-la em sua relação inexorável com o luto e o esquecimento. Como nos diz Gagnebin (1999, p. 3),

Se podemos assim ler as histórias que a humanidade se conta a si mesma como o fluxo constitutivo da memória e, portanto, de sua identidade, nem por isso o próprio movimento da narração deixa de ser atravessado, de maneira geralmente mais subterrânea, pelo refluxo do esquecimento.

Arriscamos, então, entender o esquecimento não apenas no sentido de algo 
que é ditado ou ensinado a esquecer, determinante social, imperativo de tornar não-dito/silenciar, mas na condição de "par-chave" junto à memória, habitando a produção de todos os capítulos de uma história, venha ela a ser contada ou não no cotidiano da cidade.

Dessa forma, os acontecimentos e personagens apagados tensionam o espaço-tempo da cidade através de memórias espectrais, ou esquecimentos latentes à espera de condições que os façam pulsar. Experimentar a cidade de modo a escutar o que ainda ressoa das histórias de camadas submersas foi tarefa tratada por Benjamin e apontada por Szondi (2016) ao tratar das iluminações sobre cidades presentes em Benjamin. Segundo Szondi (2016), em Benjamin temos que a viagem ao passado é também uma viagem para um "lugar" distante, pois não há nenhuma descrição sem distância. Nessa relação exotópica de distanciamento temporal dos acontecimentos referentes à história do espaço urbano, procurar por iluminações, lampejos de memórias citadinas que afrontam passado e presente, tensiona a própria condição de separação entre "memória X esquecimento" em que se costumam depositar os acúmulos de tempos históricos das cidades e das vidas a ela tramadas. Parece ser uma tarefa possível, se entendemos que condições de experiências com um fato já ocorrido ainda resistem no contemporâneo.

\section{Considerações finais}

Através da experimentação da cidade vivenciada na intervenção urbana Parte da Paisagem, foi possível trabalhar com as questões referentes às (in)visibilidades, ao ordinário ou enaltecido, ao par-chave memória e esquecimento presente nas histórias e suas lacunas sobre a existência do Rio da Bulha e a população que o margeava. Foi possível também compreender a dimensão que a arte pode ocupar no projeto de uma memória política que recolhe restos e produz rastros sobre acontecimentos relacionados aos esquecidos através da interlocução com a estética do antimonumento. 
Postulou-se, com esta escrita, que na experiência estética na cidade, seja através da arte ou de formas outras de rupturas ao cotidiano acelerado, é possível conectar-se com experiências históricas outras com o território urbano, experiências históricas produzidas na relação entre as pessoas e a cidade, ou seja, quando as narrativas que se colhem sobre ela deixem marcas nos corpos daqueles que com elas se relacionam. É o que diz Benjamin (2012) em "O Narrador" sobre a forma artesanal da narrativa, que imprime as marcas do narrador naquilo que ele produz. E a abertura à produção dessas marcas em nossos corpos a partir de certas relações vivenciadas com a cidade é que parecem nos deslocar de uma relação estritamente rotineira com a mesma.

Na discussão sobre algumas tensões presentes no espaço urbano, nas compreensões sobre o "esquecimento" que compõe os conteúdos memorativos, pudemos neste trabalho discutir sobre (in)visibilidades e possibilidades de ressurgimento das narrativas relacionadas à história de um rio que comporta muitos ruídos. Um rio esquecido, escondido, mas que continua a resistir ao apagamento dos vestígios de sua presença e das vidas a ele e ao seu entorno amalgamadas.

\section{Referências}

BAKHTIN, M. O tempo e o espaço nas obras de Goethe. Estética da criação verbal. Traduzido por P. Bezerra. 5. ed. São Paulo: WMF Martins Fontes, 2003.

BARRENTO, J. "Percepção é leitura": a cidade, o olhar, a memória. Limiares sobre Walter Benjamin. Florianópolis: Ed. UFSC, 2013.

BENJAMIN, Walter. Sobre o conceito da história. Magia e Técnica, Arte e Política. Obras Escolhidas. vol. 1. São Paulo: Brasiliense, 1994.

BENJAMIN, Walter. A obra de arte na era de sua reprodutibilidade técnica. Obras escolhidas. vol. 1. Tradução de S. P. Rouanet. 8. ed. São Paulo: Brasiliense, 2012.

CABRAL, O. R. Nossa Senhora do Desterro: Notícias, vol. I. Florianópolis: Imprensa da Universidade Federal de Santa Catarina, 1971. 
DIDI-HUBERMAN, Georges. A imagem Sobrevivente. História da arte e tempo dos fantasmas segundo Aby Warburg. Rio de Janeiro: Contraponto, 2013.

DIDI-HUBERMAN, Georges (org.). Levantes. São Paulo: Edições Sesc, 2017.

DIDI-HUBERMAN, Georges. Sobrevivência dos vaga-lumes. Belo Horizonte: UFMG, 2011.

FONSECA, T. G. Túmulo e palavra: o "After life" para prolongar um último toque com a ponta dos dedos. In: FONSECA, T. G. (org.). Imagens do fora: um arquivo da loucura. Porto Alegre: Sulina, 2018.

GAGNEBIN, J. M. Introdução. História e Narração em W. Benjamin. 2. ed. São Paulo: Ed. Perspectiva, 1999.

HISSA, C. E. V.; NOGUEIRA, M. L. M. Cidade-corpo. Rev. UFMG, v. 20, n. 1, p. 54-77, 2013. Disponível em: https://www.ufmg.br/revistaufmg/downloads/20/3-cidadecorpo cassio hissa e maria nogueira.pdf. Acesso em: 22. nov. 2019.

RANCIÈRE, J. O desentendimento. São Paulo: Editora 34, 1996.

SZONDI, Peter. Iluminaciones sobre ciudades en Benjamin: y otros ensayos. Traduzido por H. A. Murena. 1. ed. Ciudad Autonoma de Buenos Aires: El cuenco de plata, 2016.

SANTOS, A. L. Do mar ao morro: a geografia histórica da pobreza urbana em Florianópolis. 2009. Tese (Doutorado em Geografia) - Programa de Pós-Graduação em Geografia, Centro de Filosofia e Ciências Humanas, Universidade Federal de Santa Catarina, Florianópolis, 2009. Disponível em: http://www.tede.ufsc.br/teses/PGCN0383-T.pdf. Acesso em: 22 nov. 2019.

SANTOS, F.; PEREIRA, R. Análise histórico-espacial do setor hoteleiro no núcleo urbano central de Florianópolis-SC. Geosul, v.23, n.46, p. 115-135, 2008. DOI https://doi.org/10.5007/2177-5230.2008v23n46p115

SELIGMANN-SILVA, M. Antimonumentos: trabalho de memória e de resistência. Rev. Psicologia USP, v. 27, n. 1, 2016, p. 49-60, 2016. Disponível em: http://www.scielo.br/pdf/pusp/v27n1/1678-5177-pusp-27-01-00049.pdf. Acesso em: 22 nov. 2019.

SCHMITT, M. Z. J. As memórias do tempo livre de trabalhadores e trabalhadoras em Florianópolis. Esboços: histórias em contextos globais, v.8, n. 8, 2000, p. 87100.

Disponível

em: https://periodicos.ufsc.br/index.php/esbocos/article/view/616/20101. Acesso em: 29 fev. 2020. 
WEINRICH, H. Lete: arte e crítica do esquecimento. Rio de Janeiro: Civilização Brasileira, 2001.

ZANELLA, A. Atividade, significação e constituição do sujeito. Psicologia em Estudo, Maringá, v. 9, n. 1, p. 127-135, 2004. Disponível em: http://www.scielo.br/pdf/pe/v9n1/v9n1a16. Acesso em: 22 nov. 2019.

Recebido em: 06/12/2019 Aprovado em: 09/03/2020 